fishes, and the mangrove swamp and barracouta groups. In addition to these are exhibits of corals, sponges, starfishes and shells. In the panel display of shells an effective mosaic-like background of different pastel shades was used to good effect. The large habitat-group of South African mammals devoted to the herbivores of the Kruger National Park was revised. Seven large mural panels painted by the Director wore hung on the first landing of the Museum and form an arresting feature as the building is entered. Several collecting journeys have been made to Portuguese East Africa, eastern Swaziland, Kenya and Tanganyika. In the Art Gallery a revision was made of the hanging of the permanent collection.

\section{Florida State Museum}

THE Director's report of the Florida State Museum for 1960-61 records an accelerated programme of exhibits to meet the expanding needs of the Museum (Pp. 24. Gainesville, Flo.: Florida State Museum, 1961). To further public relations activities, a lively programme of temporary exhibits was presented during the year. Special exhibits of recent acquisitions to the collections were made from time to time. The year saw the continued growth of the research collections and the greater use of the collections by others than the staff. The Museum, which is part of the University of Florida, recognizes the importance of its role as a unit of research and instruction.

\section{National Forest Parks in Britain}

The original policy of the Forestry Commission was essentially concerned with the creation of a strategic reserve of timber and this was to be achieved mainly by afforestation. It could be argued that some of the aspects of what are considered to be essential to a national forest policy were omitted or not obvious in the original policy, but it has, through circumstances, altered. One very welcome change which the Forestry Commission has been able to introduce is concerned with amenity, in particular the establishment of National Forest Parks which are open for public enjoyment. Argyll National Park was the first, opened in 1935, and there are now seven. Individual National Forest Park guides are available, but the recently published Booklet No. 6, entitled National Forest Parks, is a generalized account of these parks, and it also includes the New Forest which, though not a National Forest Park, does provide similar scope for recreation and camping (Forestry Commission. Booklet No. 6. Pp. 40. London: H.M. Stationery Office, 1961. 2s. 6d. net). There are, as well, notes on two arboreta and a forest garden open to the public. It is to be hoped that this very attractive booklet will find a wide circulation and so help to stimulate the British people to appreciate, love and enjoy their forests.

\section{Antigens of Tapeworms}

STUDY of the taxonomy of the tapeworms revoals a mass of confusing information. Among the cestodes affecting man and his domestic animals there are grounds for doubt as to the identity of even the common forms. In an attempt to clarify the position, S. E. Maddison, H. Whittle and R. Elsdon-Dew have carried out a series of immunological investigations (South Afric. J. Sci., 10; October 1961). The experimonts were concerned with the immune response to infestations with the larval forms of various cestodes. The results show the complexity of the antigenantibody against larval cestodes, and indicate the need for maximum caution in their interpretation. There are apparently both generic and specific antigens. Further work must be done to elucidate the problem, and trial experiments indicate that immunoelectrophoresis and chemical fractionation of the antigens will be useful. It is clear, however, that though there are common components, the cysterei from pork and from beef show differing antigens. This reduces the possibility that some pork measles may be due to larval forms of $T$. saginata. When examined in relation to anti-pork cysticercus serum, there stppears to be a close antigenic relationship between the larvæ causing pork cysticercosis, beef cysticercosis and 'tenuicollis'. The hydatid antigens are somewhat distinct from these; the differences, however, may be mainly quantitative in nature.

\section{Fishery Research Training Grants}

The Development Commissioners are offering, in association with the Ministry of Agriculture, Fisheries and Food and the Department of Agriculture and Fisheries for Scotland, postgraduate training grants in fishery research tenable from October 1. These grants are intended to enable selected candidates to undergo a specified course of training to fit them for the investigation of problems in marine or freshwater science. The Commissioners will consider applications from candidates to register for a higher degree in circumstances where this seems likely to be consistent with the requirements of the approved fishery research training programme. The number of training grants to be awarded in 1962 will probably not exceed four, and candidates must be British subjects and should be graduates with honours in science in a British university or possess equivalent qualifications; both men and women are eligible to apply. The value of the training grant will depend on the centre at which training is undertaken, and on whether the student is able to live at home, but will not normally be less than $£ 270$ nor exceed $£ 470$ per annum. Further information and forms of application, returnable by March 20, can be obtained from the Secretary, Development Commission, 3 Dean's Yard, Westminster, London, S.W.1.

\section{IBM Research Endowment Fund}

IBM United Kingdom, Ltd., continuing with its policy of some years past, has instituted a Research Endowment Fund under which free time is given on the full range of IBM equipment free of charge to approved academic and humanitarian research of a non-profit making nature. Applications for free time on the IBM 7090, or other appropriate machines, are assessed by an independent consultant panel consisting of Sir Austin Bradford Hill, professor emeritus of medical statistics, University of London; Prof. Fred Hoyle, Plumian professor of astronomy and experimental philosophy, University of Cambridge; and Mr. M. V. Wilkes, director of the Mathematical Laboratory, University of Cambridge. In the past six months computer time has been given for research into problems of reactor systems, semi-conductors, physiology, ophthalmology, virology, etc. A total of twenty hours on the ABM 7090, or the equivalent on other machines, is reserved for 1962 and applications for free time are invited. Further information can be obtained from the Press and Public Relations Office, 